\title{
SELF-FORMATION OF Fe/Fe-O NANOPARTICLES IN POROUS $\mathrm{SiO}_{2}$ FILMS*
}

\author{
I. Šimkienè ${ }^{\text {a,b }}$, J. Sabataitytė ${ }^{\text {a,c }}$, M. Baran ${ }^{\text {d }}$, R. Szymczak ${ }^{\text {d }, ~ J .-G . ~ B a b o n a s ~}{ }^{\text {a,c }}$, \\ A. Rèza ${ }^{\text {a,e }}$, and A. Kaliničenko ${ }^{f}$ \\ ${ }^{a}$ Semiconductor Physics Institute, A. Goštauto 11, LT-01108 Vilnius, Lithuania \\ ${ }^{\mathrm{b}}$ Vilnius University, Sauletekio 9, LT-10222 Vilnius, Lithuania \\ ${ }^{\mathrm{c}}$ Vilnius Gediminas Technical University, Saulettekio 11, LT-10223 Vilnius, Lithuania \\ ${ }^{\mathrm{d}}$ Institute of Physics, PAN, Al. Lotnikow 32/46, 02-668 Warsaw, Poland \\ e Vilnius Pedagogical University, Studentu 39, LT-08106 Vilnius, Lithuania \\ ${ }^{\mathrm{f}}$ Institute of Chemistry, A. Goštauto 10, LT-01108 Vilnius, Lithuania
}

Received 13 June 2005

\begin{abstract}
Self-formation of $\mathrm{Fe} / \mathrm{Fe}-\mathrm{O}$ particles in porous $\mathrm{SiO}_{2}$ films has been studied by investigating the structure and physical properties of hybrid samples $\mathrm{SiO}_{2}: \mathrm{Fe} / \mathrm{SiO}_{2} / \mathrm{Si}$. The sol-gel spin-on technique was used for the formation of Fe-doped silica films on silica-coated Si wafers. The sol was prepared from precursors composed of ethanol and/or aqueous solutions of tetraethoxysilane (TEOS) and $\mathrm{FeCl}_{3}$. As-grown hybrid samples were annealed in $\mathrm{Ar}$ atmosphere. Structural studies by means of atomic force microscopy (AFM) have shown a different morphology of samples produced from precursors with various Fe-amount. Spectroscopic ellipsometry measurements were carried out for characterization of the contribution of $\mathrm{Fe} / \mathrm{Fe}-\mathrm{O}$ clusters to the optical response of hybrid samples. Magnetic properties of Fe-doped silica films were studied by measuring the magnetic field and temperature dependences of magnetization. Experimental data were interpreted taking into account particular features of $\mathrm{Fe}$ and $\mathrm{Fe}-\mathrm{O}$ nanoparticles in silica matrix.
\end{abstract}

Keywords: nanoscale materials and structures, fabrication and characterization

PACS: 81.07.-b, 81.16.Dn

\section{Introduction}

Self-formation is a general principle describing the structural ordering of the system without external influence [1]. During the last decade, this principle was used in nanotechnology as the "bottom-up" technique to arrange structurally the assembly of nanometric particles [2]. For example, the self-assembled system of colloidal nanoparticles can form, on the one hand, the diamond-like structure with the properties typical of photonic crystal [3]. On the other hand, porous matrices of metals, metal oxides, and semiconductors can be grown from colloidal solution under specific technological conditions [4].

Recently, low-cost room-temperature sol-gel process was applied in nanotechnology [5], in particular in the formation of porous insulating matrices [6]. The sol-gel technique provides also a convenient method to obtain hybrid samples using precursors presenting

\footnotetext{
* The report presented at the 36th Lithuanian National Physics Conference, 16-18 June 2005, Vilnius, Lithuania.
}

the mixture of various materials. The self-formation of magnetic nanoparticles in nanopores of insulating matrices was widely studied in bulk samples [6]. However, instead of bulk insulating matrices, multilayer structures produced by planar technology using a spinon technique are the most promising systems for practical applications. Silica layers of controlled porosity were produced on $\mathrm{Si}$ wafers by varying the technological procedure [7]. It was found that physical properties of hybrid samples containing $\mathrm{Fe} / \mathrm{Fe}-\mathrm{O}$ particles in silica on Si depended critically on the chemical composition of precursors $\left(\mathrm{FeCl}_{3}\right.$ and $\left.\mathrm{Fe}\left(\mathrm{CH}_{3} \mathrm{COO}\right)_{3}\right)$ [8], technological procedure ("one-pot" and "two-pots" technique) [9], as well as on the post-growth thermal treatment in various atmospheres (air, $\mathrm{Ar}$, and $\mathrm{H}_{2}$ ) [7]. The magnetic properties were mostly expressed in the $\mathrm{SiO}_{2}: \mathrm{Fe} / \mathrm{SiO}_{2} / \mathrm{Si}$ samples annealed in hydrogen [8].

In this work, hybrid samples $\mathrm{SiO}_{2}: \mathrm{Fe} / \mathrm{Si}$, which have been produced from $\mathrm{FeCl}_{3}$ precursor and annealed in Ar atmosphere, were studied. The structure of selforganized $\mathrm{Fe} / \mathrm{Fe}-\mathrm{O}$ clusters in silica was investigated by 
atomic force microscopy (AFM). The optical response and magnetization of hybrid samples were analyzed and correlated with particular features of the structure.

\section{Experimental}

The hybrid samples $\mathrm{SiO}_{2}: \mathrm{Fe} / \mathrm{Si}$ were prepared by sol-gel spin-on technique described in [8] in more detail. The aqueous solution of $\mathrm{FeCl}_{3}$ was mixed with either freshly prepared colloidal ethanol solution of tetraethoxysilane (TEOS) ("one-pot" reaction) or with structurized TEOS sol ("two-pots" reaction). The acidity of coating solutions was in the range of $\mathrm{pH}$ values 1.9-2.1. The coating solution was deposited by spinning at $2500 \mathrm{rpm}$ on $n-\mathrm{Si}(0.5 \Omega \cdot \mathrm{cm})(100)$-oriented wafers, which usually have been already coated by silica using the same sol-gel spin-on technique. Multiple layer structures composed of one or two Fe-doped silica layers on up to four silica layers were prepared. After deposition of each layer, the samples were dried in air at $95{ }^{\circ} \mathrm{C}$ for $0.5 \mathrm{~h}$ and the hybrid samples $\mathrm{SiO}_{2}: \mathrm{Fe} / \mathrm{SiO}_{2} / \mathrm{Si}$ were annealed in $\mathrm{Ar}$ atmosphere at $550{ }^{\circ} \mathrm{C}$ for $2 \mathrm{~h}$ and then cooled down in the same atmosphere to room temperature.

The structure of the samples was investigated by a standard atomic force microscope (AFM) Thermomicroscope Explorer. The optical properties of the samples were studied by means of spectroscopic ellipsometer with rotating analyzer operating at room temperature in the range of $1-5 \mathrm{eV}$. The spectra of ellipsometric parameters $\Psi$ and $\Delta$ were analyzed in a multilayer model [8]. The magnetization of the samples was measured as a function of magnetic field (up to $5 \mathrm{~T}$ ) and temperature (5-300 K) using a commercial SQUID magnetometer (MPMS-5, Quantum Design). The magnetic field was oriented in the plane of the films.

\section{Results and discussion}

\subsection{Structural features}

The process of self-formation of Fe-containing nanoparticles and clusters depends on chemical composition of precursor, conditions of growth procedure, and postgrowth thermal treatment [7-9]. The hybrid samples under investigation were prepared from the same precursor containing $\mathrm{FeCl}_{3}$ and annealed in the same $\mathrm{Ar}$ atmosphere. Thus, the intrinsic structure of Fe-doped films depended mainly on the growth conditions.

As noted above, the Fe-doped silica layer was usually deposited on the silica-coated Si wafers. The sol-
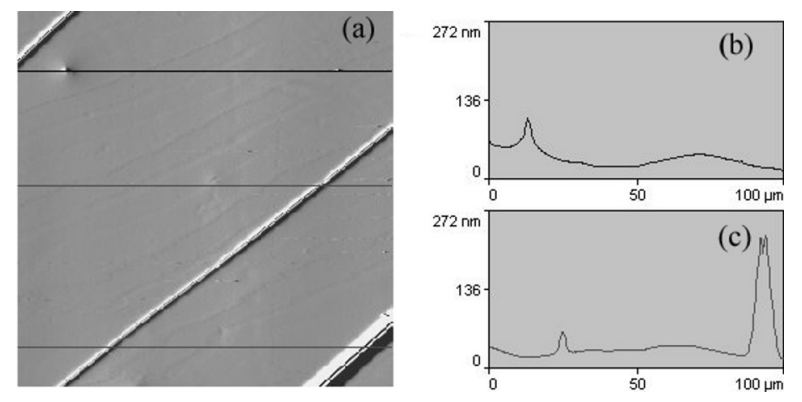

Fig. 1. (a) Morphology and surface roughness profile at (b) upper and (c) lower horizontal lines shown in (a) of thick $(d \sim 800 \mathrm{~nm})$ $\mathrm{Au}$-decorated $\mathrm{SiO}_{2}$ layer. The surface area in (a) AFM micrograph is $100 \times 100 \mu \mathrm{m}^{2}$.

gel spin-on processed silica layers on the Si surface, which have been dried at $\sim 100{ }^{\circ} \mathrm{C}$ for $1 \mathrm{~h}$, were dense with porosity of $\sim 10 \%$ at the centre of $\mathrm{Si}$ wafer with diameter of $5 \mathrm{~cm}$, and $5 \%$ at the edge [10]. However, when $\mathrm{Si}$ wafers of a smaller diameter $(1-2 \mathrm{~cm})$ were used, the roughness of the surface was $\sim 250 \mathrm{~nm}$ due to formation of clusters composed of rectangular-shaped particles of size $\sim 50 \times 50 \mathrm{~nm}^{2}$ and $\sim 50 \mathrm{~nm}$ in height [10]. The cracks were revealed on Au-decorated thick silica films (Fig. 1) of thickness $d \geq 800 \mathrm{~nm}$. It is interesting to note that the cracks, which were most probably due to large internal stress in silica layer, were oriented along crystallographic axes of $\mathrm{Si}(100)$ wafers.

When aqueous solution of the salt $\mathrm{FeCl}_{3} \cdot 6 \mathrm{H}_{2} \mathrm{O}$ is prepared, the hydrolysis takes place:

$$
\mathrm{FeCl}_{3}+3 \mathrm{H}_{2} \mathrm{O}=\mathrm{Fe}(\mathrm{OH})_{3} \downarrow+3 \mathrm{HCl} .
$$

As the solution is prepared at room temperature, the hydrolysis is not an intensive process. As a result, on the one hand, $\mathrm{FeCl}_{3}$ was not completely hydrolized. On the other hand, active molecules of $\mathrm{Fe}(\mathrm{OH})_{3}$ joined together as $\mathrm{Fe}(\mathrm{OH})_{m}$ forming the core of colloidal particle, at the surface of which $\mathrm{Fe}^{3+}$ ions were adsorbed. In the precursor solution, the $\mathrm{Fe}(\mathrm{OH})_{m}$ particles form the complexes with the particles of silicon hydroxide due to intensive hydrolysis and condensation of TEOS. As a result of these chemical reactions, significant amount of excess water is present in the Fe-doped layer deposited on Si wafer in the sol-gel spin-on process.

Annealing in Ar atmosphere at a relatively high temperature $\left(550{ }^{\circ} \mathrm{C}\right)$, in contrast to thermal treatment in $\mathrm{H}_{2}$ [8], leads to an intensive water evaporation and local destruction of Fe-doped $\mathrm{SiO}_{2}$ film (Fig. 2). The defects of size $l \sim 30 \mu \mathrm{m}$ and height $h=1.3-1.5 \mu \mathrm{m}$ were seen on the surface of these hybrid samples. It should be noticed (Fig. 2) that the defect of this type presented the centre where $\mathrm{Fe}$ particles were accumulated from surroundings of $\sim 50 \mu \mathrm{m}$ size. Micro- 


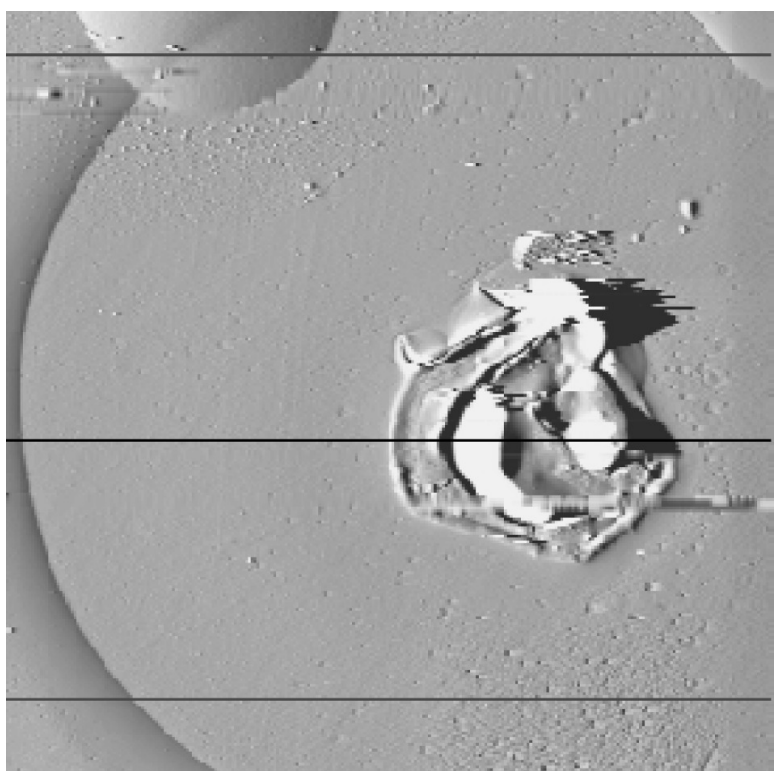

Fig. 2. AFM micrograph $\left(100 \times 100 \mu \mathrm{m}^{2}\right)$ of Fe-doped film in the vicinity of defect formed due to intensive water evaporation.

analysis of chemical composition confirmed [8] the formation of Fe-depleted region around the defects. This observation indicates that accumulation of Fecontaining clusters is closely related to the hydroxides of $\mathrm{Fe}$ and $\mathrm{Si}$. Indeed, as is known [11], iron oxides and hydroxides adsorb intensively the water molecules. As a result, $\mathrm{Fe}(\mathrm{OH})_{m}$ clusters are surrounded by water molecules. When Fe-doped films were dried at $\sim 100{ }^{\circ} \mathrm{C}$, iron hydroxide transformed to goethite $(\alpha-\mathrm{FeOOH})$ or lapidocrocite $(\gamma-\mathrm{FeOOH})$ :

$$
\mathrm{Fe}(\mathrm{OH})_{3}=(\alpha, \gamma)-\mathrm{FeOOH}+\mathrm{H}_{2} \mathrm{O} .
$$

Analysis of chemical reactions [12] allows one to assume that in Ar-annealed Fe-doped films, i.e., at annealing in oxygen-depleted atmosphere, Fe-oxides formed nanoparticles of magnetite $\mathrm{Fe}_{3} \mathrm{O}_{4}$ and maghemite $\gamma-\mathrm{Fe}_{2} \mathrm{O}_{3}$, in contrast to $\mathrm{H}_{2}$-annealed $\mathrm{Fe}$-doped sil-

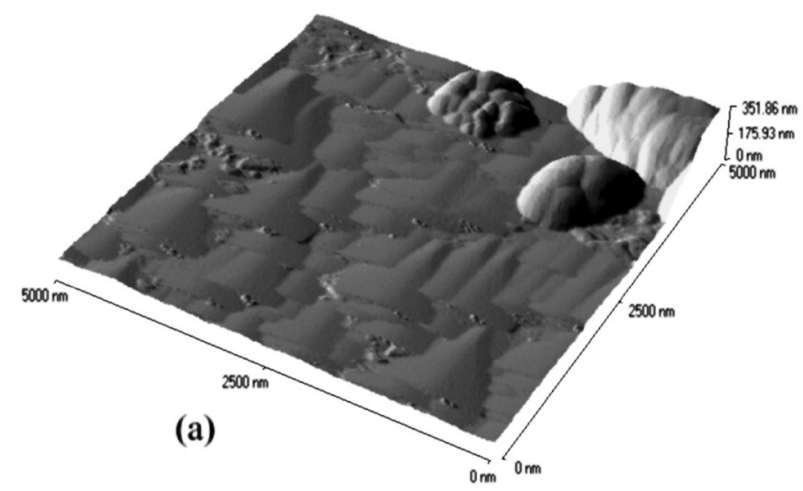

ica, in which mainly metal $\mathrm{Fe}$ nanoparticles were formed [8]. Under oxidation, magnetite $\mathrm{Fe}_{3} \mathrm{O}_{4}$ transformed to $\gamma-\mathrm{Fe}_{2} \mathrm{O}_{3}$.

As follows from Fig. 3, the self-formation of Fe clusters in $\mathrm{Fe}$-doped $\mathrm{SiO}_{2}$ layers is a complicated process resulting in occurrence of large meso $(l \sim 20 \mu \mathrm{m}$, $h \sim 1.5 \mu \mathrm{m})$, macro $(l \sim 5 \mu \mathrm{m}, h \sim 0.5 \mu \mathrm{m})$, and micro $(l \sim 1 \mu \mathrm{m}, h \sim 150 \mathrm{~nm})$ clusters. However, as seen from Fig. 3(b), the clusters composed of isolated nanoparticles $(l \sim 50-100 \mathrm{~nm}, h \sim 20-50 \mathrm{~nm})$ were inserted into the pores of silica background forming rectangular plates $(l \sim 500 \mathrm{~nm}, h \sim 10-20 \mathrm{~nm})$.

Figure 4 illustrates a different shape of Fe-containing particles in hybrid $\mathrm{SiO}_{2}: \mathrm{Fe} / \mathrm{SiO}_{2} / \mathrm{Si}$ samples, in which $\mathrm{SiO}_{2}$ structure of rectangular-shaped plates was not clearly developed. On the one hand (Fig. 4(a)), large ring-like structures $(\sim 10 \mu \mathrm{m})$ and macro clusters composed of nanoparticles $(l=50-200 \mathrm{~nm}, h=10-$ $20 \mathrm{~nm}$ ) were formed. On the other hand (Fig. 4(b)), Fe-depleted regions $(\sim 10-20 \mu \mathrm{m})$, from which Fecontaining nanoparticles accumulated into macroclusters, were also seen. This observation possibly indicates two subsequent stages of self-formation of $\mathrm{Fe}$ containing clusters in $\mathrm{SiO}_{2}$ layers. In the first stage (Fig. 4(a)), the Fe-nanoparticles are grouped. In the second stage (Fig. 4(b)), Fe-containing particles from neighbouring area accumulate into macrocluster. The difference in the shape of macroclusters in various samples (compare Figs. 2 and 4(b)) can be caused by different content of water, which has evaporated at the drying and annealing processes.

\subsection{Optical properties}

As it is known [13], ellipsometry is a very sensitive technique for detection of thin surface layers. Nullellipsometry can be efficiently used [10] for estimation

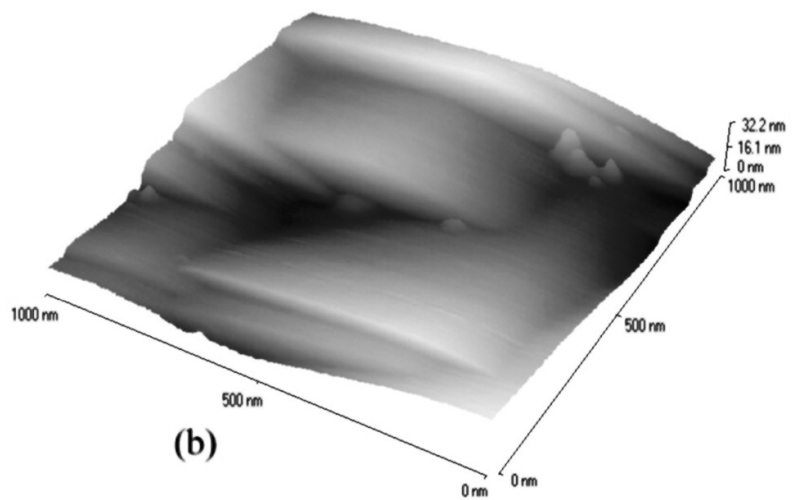

Fig. 3. (a) Small and (b) nano Fe-containing clusters on the background of silica with rectangular-like structure. The area of AFM micrograph of Fe-doped silica film in hybrid sample is (a) $5 \times 5 \mu \mathrm{m}^{2}$ and (b) $1 \times 1 \mu \mathrm{m}^{2}$. 

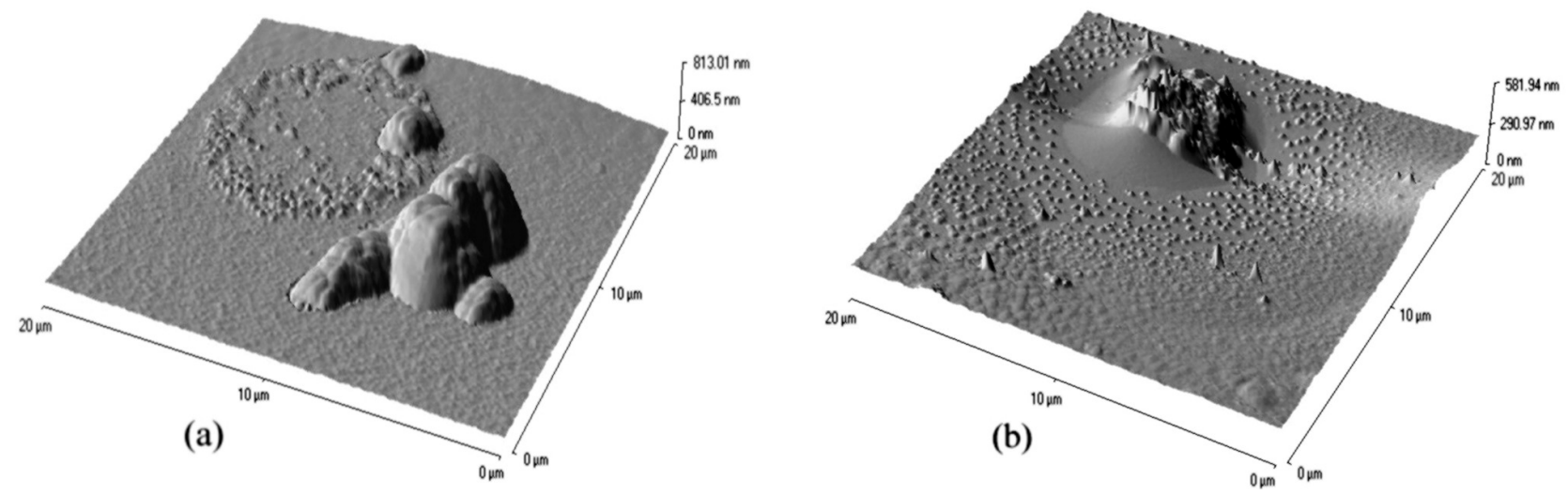

Fig. 4. AFM micrographs $\left(20 \times 20 \mu \mathrm{m}^{2}\right)$ of $\mathrm{SiO}_{2}: \mathrm{Fe} / \mathrm{SiO}_{2} / \mathrm{Si}$ hybrid samples (a) No. 33 and (b) No. 48 with higher magnetization.
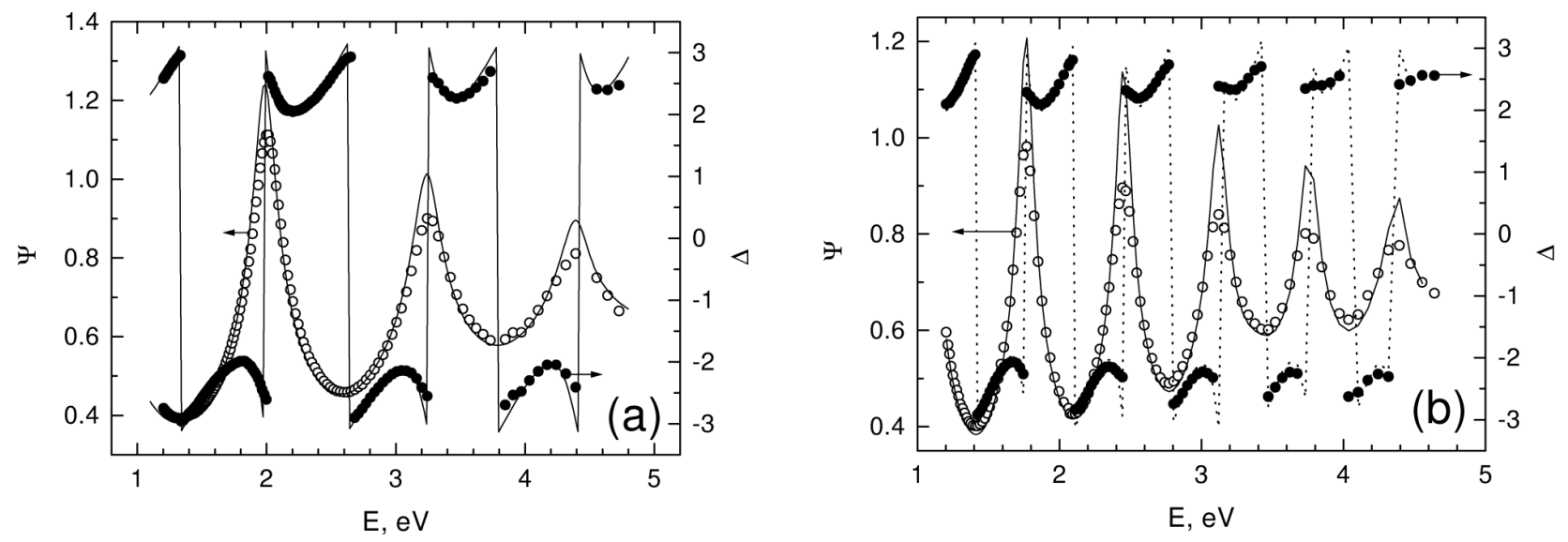

Fig. 5. Experimental (points) and modelled (curves) spectra of ellipsometric parameters characterizing the optical response of (a) two layers $(d=390 \mathrm{~nm})$ and (b) four layers $(d=750 \mathrm{~nm})$ of $\mathrm{SiO}_{2}$ deposited on $\mathrm{Si}$ wafers.

of porosity of $\mathrm{SiO}_{2}$ films on $\mathrm{Si}$. In the case of nonhomogeneous surface films, spectroscopic ellipsometry allows one to determine in-depth variation of optical characteristics [14]. When composite/hybrid films are studied, lateral non-homogeneity can be taken into account [7-9] by introducing effective medium models [15].

Figure 5 presents ellipsometric data for multiple $\mathrm{SiO}_{2}$ layers deposited on $\mathrm{Si}$ by sol-gel spin-on technique. As it is seen, the interference pattern dominates in the spectra and the experimental results can be well described by the model of one effective layer with reference data for $\mathrm{SiO}_{2}$ [16] even in the case of four $\mathrm{SiO}_{2}$ layers deposited subsequently on Si-substrate. However, in the latter case, the average value of porosity of thick (thickness $d=750 \mathrm{~nm}$ ) silica films estimated from fitting procedure increased up to $2.5 \%$ due to both intrinsic porosity and roughness. Comparison of data shown in Fig. 5 indicates that surface roughness is significant and it increases for thicker film, leading to a decrease of interferometer quality, which has not be taken into account in the present modelling.

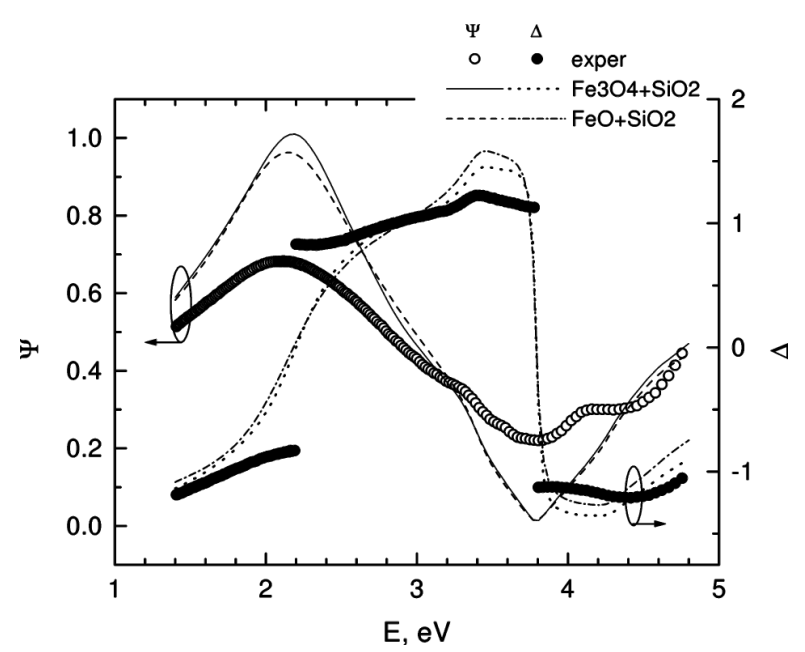

Fig. 6. Experimental (points) and modelled (curves) spectra of ellipsometric parameters in the optical response of $\mathrm{SiO}_{2}: \mathrm{Fe} / \mathrm{Si}$ hybrid sample with $\mathrm{SiO}_{2}: \mathrm{Fe}$ layer grown by "two-pots" technique. The modelled spectra were calculated assuming the presence of $\mathrm{Fe}_{3} \mathrm{O}_{4}$ and $\mathrm{FeO}$ in $\mathrm{SiO}_{2}$ film.

Ellipsometric data for $\mathrm{SiO}_{2}: \mathrm{Fe} / \mathrm{Si}$ hybrid sample produced by "two-pots" technique are shown in Fig. 6. In the calculations, reference data for magnetite $\mathrm{Fe}_{3} \mathrm{O}_{4}$ 

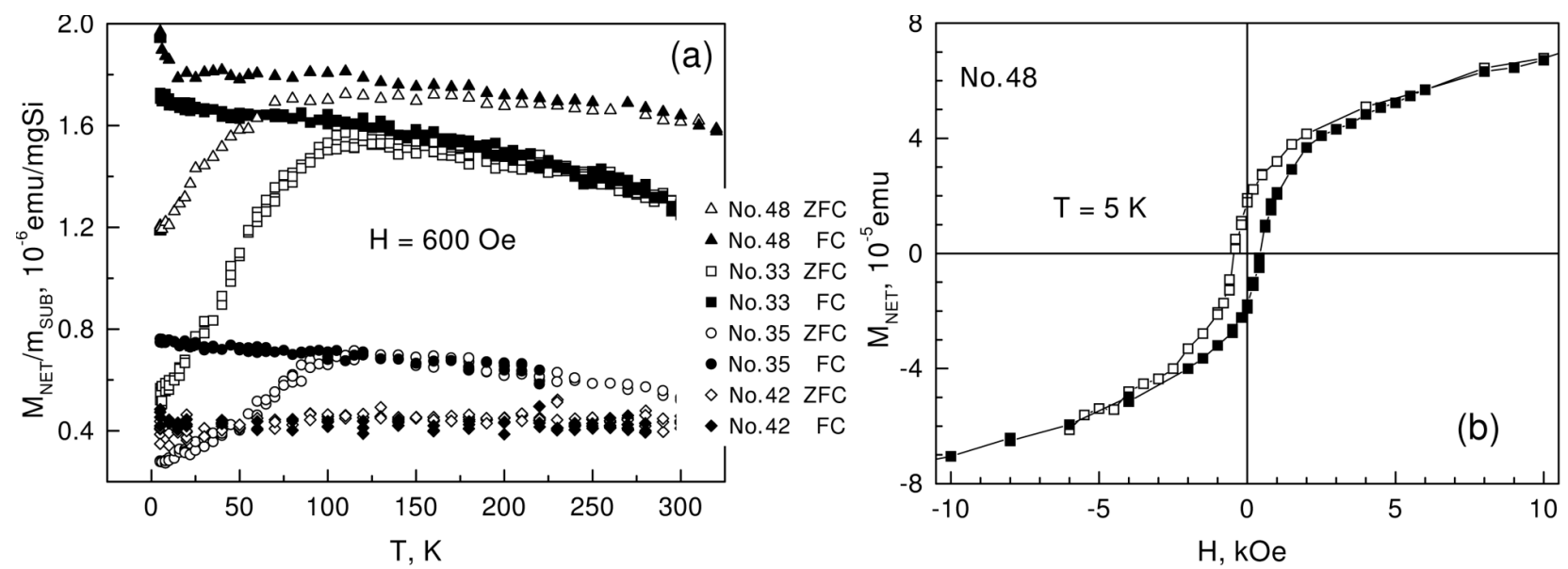

Fig. 7. (a) Temperature and (b) magnetic field dependences of magnetization in hybrid samples $\mathrm{SiO}_{2}: \mathrm{Fe} / \mathrm{SiO}_{2} / \mathrm{Si}$ annealed in $\mathrm{Ar}$ atmosphere.

[17] and wustite $\mathrm{FeO}$ [18] were used to model the effective media composed of a mixture of iron oxides and $\mathrm{SiO}_{2}$. As it is seen, the spectra of ellipsometric parameters are caused by a dominant contribution of interference in the $\mathrm{SiO}_{2}: \mathrm{Fe}$ film of thickness $d \sim 120 \mathrm{~nm}$. In addition, small influence of the reflectance from $\mathrm{SiO}_{2}: \mathrm{Fe}-\mathrm{Si}$ interface can be noticed, which manifests itself by optical features at 3.4 and $4.3 \mathrm{eV}$ characteristic of $\mathrm{Si}$. However, in this case the amount of Fe-O was too small to determine particular iron oxide with a dominant contribution to the optical response.

It should be noticed that there are size limits for metal inclusions for the validity of effective media theory [19]. For example, in the case of $\mathrm{Co}$ in $\mathrm{Al}_{2} \mathrm{O}_{3}$, the limiting radius of metal inclusions is $\sim 40 \mathrm{~nm}$ at filling factor 0.3 for the measurements of $5 \%$ accuracy at $1 \mu \mathrm{m}$. In addition, corrections due to depolarization of light should be taken into account in the analysis of spectroscopic ellipsometry data [20]. Therefore, the ellipsometric data can be rather qualitatively interpreted $[10,21]$ by comparing the dielectric function of effective medium, which has been obtained from fitting procedure, with the reference data.

\subsection{Magnetization}

Figure 7 illustrates the temperature and magnetic field dependences of magnetization $M$ in hybrid $\mathrm{SiO}_{2}: \mathrm{Fe} / \mathrm{SiO}_{2} / \mathrm{Si}$ samples. The magnetization of hybrid samples $M_{\mathrm{NET}}$ was corrected by extracting magnetization of $\mathrm{SiO}_{2} / \mathrm{Si}$-substrates. The $M_{\mathrm{NET}} / m_{\mathrm{SUB}}$ values were also normalized to the mass of each substrate. Assuming that the thickness of $\mathrm{SiO}_{2}: \mathrm{Fe}$ films is equal in all hybrid samples, the value of $M_{\mathrm{NET}} / m_{\mathrm{SUB}}$ corresponds to the magnetization of unit volume $\left(\mathrm{emu} / \mathrm{cm}^{3}\right)$. As follows from Fig. 7(a), the magnetization of hybrid samples with expressed structure of silica (sample No. 42) is considerably smaller than that of the samples with Fe-accumulated clusters (Nos. 33, 35, 48). The second group samples have shown similar temperature dependence of magnetization, whereas the difference in $M(T)$ values can be due to various thickness of $\mathrm{SiO}_{2}: \mathrm{Fe}$ films. However, the variation in the temperature values, at which the difference of magnetization for the field cooled (FC) and zero-field cooled (ZFC) runs vanishes, correlates with the absolute value of magnetization $M$ and can happen due to different mean size of Fe-containing clusters. The $M(T)$ dependences at FC runs are only slightly dependent on $T$, indicating that short-range magnetic interactions become significant at relatively high temperatures.

The field dependences for hybrid samples of the second group have shown the hysteresis loops (Fig. 7(b)) with the $H_{\mathrm{c}}$ values equal to $450(5 \mathrm{~K}), 650(25 \mathrm{~K})$, and $1000 \mathrm{Oe}(25 \mathrm{~K})$ for samples Nos. 48,33 , and 35 , respectively. This sequence also correlates with that for absolute $M$ values. It should be noted that hysteresis loop for sample No. 48 is similar to that for bulk Fedoped silica samples annealed in $\operatorname{Ar}$ [7].

\section{Conclusion}

It is concluded that in Ar-annealed hybrid $\mathrm{SiO}_{2}: \mathrm{Fe} / \mathrm{SiO}_{2} / \mathrm{Si}$ samples, aggregates of various sizes, from nanoparticles to macroclusters, were formed. Two main types of Fe-doped films were detected. In the hybrid samples of the first type, the structure of $\mathrm{SiO}_{2}$ layer composed of rectangular-shaped plates was developed and Fe-nanoparticles were observed. Magnetic properties of these samples were not expressed. In the hybrid samples of the second type, Fe-enriched 
defects and Fe-depleted regions were observed. These samples possessed relatively strong magnetization and hysteresis loop.

\section{Acknowledgement}

This work was partially supported by the EU project PHOREMOST (No. 511616).

\section{References}

[1] http://en.wikipedia.org/wiki/.

[2] S.C. Glotzer, M.J. Solomon, and N.A. Kotov, Selfassembly: From nanoscale to microscale colloids, Amer. Inst. Chem. Engn. 50, 2978-2984 (2004).

[3] M. Maldovan and E.L. Thomas, Diamond-structured photonic crystals, Nature Materials 3, 593-600 (2004).

[4] Y. Wang, Z.Y. Tang, X.R. Liang, L.M. Liz-Marzen, and N.A. Kotov, $\mathrm{SiO}_{2}$-coated CdTe nanowires: Bristled nano centipedes, Nano Letters 4, 225-231 (2004).

[5] P. Moriarty, Nanostructured materials, Rep. Progr. Phys. 64, 297-381 (2001).

[6] B.J. Clapsaddle, A.E. Gash, J.H. Satcher, and R.L. Simpson, Silicon oxide in iron (III) oxide matrix: The sol-gel synthesis and characterization of $\mathrm{Fe}-$ Si mixed oxide nanocomposites that contain iron oxide as the major phase, J. Non-Crystal. Solids 331, 190201 (2003).

[7] I. Šimkienė, M. Baran, G.-J. Babonas, R.-A. Bendorius, A. Rėza, R. Szymczak, P. Aleshkevych, R. Šustavičiūtè, and R. Tamaševičius, Formation of ironcontaining clusters in silica of predetermined porosity, Acta Phys. Polonica A 107, 400-407 (2005).

[8] I. Šimkienė, J. Sabataitytè, J.-G. Babonas, A. Rėza, R. Szymczak, H. Szymczak, M. Baran, M. Kozlowski, and S. Gierlotka, Sol-gel processed iron-containing silica films on Si, Proc. SPIE 5946 (2005) (in print).

[9] G.J. Babonas, A. Reza, I. Simkiene, J. Sabataityte, M. Baran, R. Szymczak, U.O. Karlsson, and A. Suchodolskis, Optical properties of Fe-doped silica films on Si, Appl. Surf. Sci. (submitted).
[10] R. Šustavičiūtè, I. Šimkienè, J. Sabataitytè, A. Rèza, A. Kindurys, R. Tamaševičius, and J. Babonas, Formation and investigation of porous $\mathrm{SiO}_{2}$ films on $\mathrm{Si}$, Lithuanian J. Phys. 44, 465-476 (2004).

[11] F. Jones, A.L. Rohl, J.B. Farrow, and W. Van Bronswijk, Molecular modeling of water adsorption on hematite, Phys. Chem. Chem. Phys. 2, 3209-3216 (2000).

[12] M.P. Sharrock, Particulate magnetic recording media: A review, IEEE Trans. Magn. 25, 4374-4389 (1989).

[13] R.M.A. Azzam and N.M. Bashara, Ellipsometry and Polarized Light (North-Holland, New York, 1977).

[14] J. Rivory, Characterization of inhomogeneous dielectric films by spectroscopic ellipsometry, Thin Solid Films 313-314, 333-340 (1998).

[15] G.A. Niklasson, C.G. Granqvist, and O. Hunderi, Effective medium models for the optical properties of inhomogeneous materials, Appl. Opt. 20, 26-30 (1981).

[16] C.M. Herzinger, B. Johns, W.A. McGaham, J.A. Woolam, and W. Paulson, Ellipsometric determination of optical constants for silicon and thermally grown silicon dioxide via multi-sample, multi-wavelength, multi-angle investigation, J. Appl. Phys. 83, 3323-3336 (1998).

[17] W.F.J. Fontijn, P.J. van der Zaag, M.A.C. Devillers, V.A.M. Brabers, and R. Metselaar, Optical and magneto-optical polar Kerr spectra of $\mathrm{Fe}_{3} \mathrm{O}_{4}$ and $\mathrm{Mg}^{2+}{ }_{-}$or $\mathrm{Al}^{3+}$-substituted $\mathrm{Fe}_{3} \mathrm{O}_{4}$, Phys. Rev. B 56, 5432-5442 (1997).

[18] Th. Henning, B. Begemann, H. Mutschke, and J. Dorschner, Optical properties of oxide dust grains, Astron. Astrophys. Suppl. Ser. 112, 143-161 (1995).

[19] G.A. Niklasson and C.G. Granqvist, Optical properties and solar selectivity of coevaporated $\mathrm{Co}-\mathrm{Al}_{2} \mathrm{O}_{3}$ composite films, J. Appl. Phys. 55, 3382-3410 (1984).

[20] U. Rossow, Depolarization/mixed polarization corrections of ellipsometry spectra, Thin Solid Films 313314, 97-101 (1998).

[21] I. Simkiene, J. Sabataityte, G.J. Babonas, A. Reza, and J. Beinoras, Self-organization of porphyrin structures on Si, Mater. Sci. Eng. C (submitted). 


\title{
Fe/Fe-O NANODALELIU SAVAIMINIS SUSIDARYMAS PORĖTOSIOSE SiO ${ }_{2}$ PLĖVELĖSE
}

\author{
I. Šimkiené $\dot{e}^{\mathrm{a}, \mathrm{b}}$, J. Sabataityte ${ }^{\mathrm{a}, \mathrm{c}}$, M. Baran ${ }^{\mathrm{d}}$, R. Szymczak ${ }^{\mathrm{d}}$, J.G. Babonas ${ }^{\mathrm{a}, \mathrm{c}}$, A. Rèza ${ }^{\mathrm{a}, \mathrm{e}}$, A. Kaliničenko ${ }^{\mathrm{f}}$ \\ ${ }^{\text {a }}$ Puslaidininkiu fizikos institutas, Vilnius, Lietuva \\ ${ }^{\mathrm{b}}$ Vilniaus universitetas, Vilnius, Lietuva \\ ${ }^{\mathrm{c}}$ Vilniaus Gedimino technikos universitetas, Vilnius, Lietuva \\ ${ }^{\mathrm{d}}$ Lenkijos MA Fizikos institutas, Varšuva, Lenkija \\ e Vilniaus pedagoginis universitetas, Vilnius, Lietuva \\ ${ }^{\mathrm{f}}$ Chemijos institutas, Vilnius, Lietuva
}

\section{Santrauka}

Išnagrinètas $\mathrm{Fe} / \mathrm{Fe}-\mathrm{O}$ daleliu savaiminis susidarymas poretosiose $\mathrm{SiO}_{2}$ plèvelèse, tiriant hibridinių $\mathrm{SiO}_{2}: \mathrm{Fe} / \mathrm{SiO}_{2} / \mathrm{Si}$ dariniu sandara ir fizikines savybes. Fe priemaišintos $\mathrm{Si}$ oksido plèvelès buvo suformuotos centrifūgoje ant $\mathrm{SiO}_{2}$ sluoksniu padengtu $\mathrm{Si}$ plokštelių, panaudojant zolio-gelio metodiką. Zolis buvo paruoštas iš etanolo ir / arba vandeninių tetraetoksisilano ir $\mathrm{FeCl}_{3}$ tirpalų. Suformuoti hibridiniai dariniai buvo atkaitinti Ar atmosferoje. San- daros tyrimai atominès jègos mikroskopu parodè, kad bandinių su ¿vairiu Fe kiekiu morfologija yra skirtinga. Spektroskopinè elipsometrija atlikta, siekiant apibūdinti $\mathrm{Fe} / \mathrm{Fe}-\mathrm{O}$ klasterių indèli i $i$ hibridiniu darinių optini atsaką. Fe priemaišintų $\mathrm{SiO}_{2}$ plèvelių magnetinès savybès buvo tiriamos, matuojant magnetinio momento priklausomybes nuo magnetinio lauko ir temperatūros. Eksperimentiniai rezultatai aiškinami, atsižvelgiant $\mathfrak{i} \mathrm{Fe}$ ir Fe oksidų nanodaleliu ypatumus silicio oksido matricoje. 